\title{
Sample size for estimating average trunk diameter and plant height in eucalyptus hybrids
}

\author{
Tamanho de amostra para a estimação da média do diâmetro \\ do tronco e da altura de plantas em híbridos de eucalipto
}

\begin{abstract}
Alberto Cargnelutti Filho ${ }^{\mathrm{I}^{*}}$ Rafael Beltrame $^{\mathrm{II}}$ Dilson Antônio Bisognin ${ }^{\mathrm{I}}$ Marília Lazarotto ${ }^{\mathrm{III}}$ Clovis Roberto Haselein ${ }^{\text {IV }}$ Darci Alberto Gatto ${ }^{I I}$ Gleison Augusto dos Santos
\end{abstract}

\section{ABSTRACT}

In eucalyptus crops, it is important to determine the number of plants that need to be evaluated for a reliable inference of growth. The aim of this study was to determine the sample size needed to estimate average trunk diameter at breast height and plant height of inter-specific eucalyptus hybrids. In 6,694 plants of twelve inter-specific hybrids it was evaluated trunk diameter at breast height at three (DBH3) and seven years (DBH7) and tree height at seven years (H7) of age. The statistics: minimum, maximum, mean, variance, standard deviation, standard error, and coefficient of variation were calculated. The hypothesis of variance homogeneity was tested. The sample size was determined by re sampling with replacement of 10,000 re samples. There was an increase in the sample size from $\mathrm{DBH} 3$ to $\mathrm{H} 7$ and $\mathrm{DBH7}$. A sample size of 16 , 59 and 31 plants is adequate to estimate DBH3, DBH7 and $H 7$ means, respectively, of inter-specific hybrids of eucalyptus, with amplitude of confidence interval of $95 \%$ equal to $20 \%$ of the estimated mean.

Key words: Eucalyptus spp., number of plants, sample size, experimental planning.

RESUMO

Em povoamentos florestais de eucalipto, é importante determinar o número de plantas a serem avaliadas para que as inferências sobre o crescimento das plantas sejam confiáveis. $O$ objetivo deste trabalho foi determinar o tamanho de amostra (número de plantas) necessário para a estimação da média do diametro do tronco e da altura de planta de hibridos interespecíficos de eucalipto. Em 6.694 plantas de doze hibridos interespecificos de eucalipto, foram mensurados os diâmetros do tronco à altura do peito aos três (DAP3) e aos sete anos (DAP7) e a altura de planta aos sete anos de idade (H7). Após, foram calculadas as estatísticas: mínimo, máximo, média, variância, desvio-padrão, erro-padrão e coeficiente de variação. A seguir, testaram-se as hipóteses de homogeneidade entre as variâncias. Depois, foi determinado o tamanho de amostra por meio de reamostragem, com reposição de 10.000 reamostras. Há aumento do tamanho de amostra para a estimação da média do DAP3, da H7 e do $D A P 7$, nessa ordem. Para a estimação da média do DAP3, do DAP7 e da H7 dos hibridos interespecíficos de eucalipto, com amplitude do intervalo de confiança de 95\% igual a $20 \%$ da estimativa da média, 16, 59 e 31 plantas, respectivamente, são suficientes.

Palavras-chave: Eucalyptus spp., número de plantas, dimensionamento amostral, planejamento experimental.

\section{INTRODUCTION}

Eucalyptus forests cover large areas in Brazil, especially in the South and Southeast regions. Brazil stands out in eucalyptus production, due to the adaptation of various

\footnotetext{
'Departamento de Fitotecnia, Centro de Ciências Rurais (CCR), Universidade Federal de Santa Maria (UFSM), 97105-900, Santa Maria, RS, Brasil. E-mail: alberto.cargnelutti.filho@gmail.com. "Corresponding author.

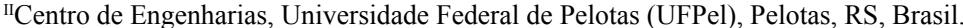

IIIDepartamento de Defesa Fitossanitária, Centro de Ciências Rurais (CCR), Universidade Federal de Santa Maria (UFSM), Santa Maria, RS, Brasil.

${ }^{\text {IV }}$ Departamento de Ciências Florestais, Centro de Ciências Rurais (CCR), Universidade Federal de Santa Maria (UFSM), Santa Maria, RS, Brasil.

${ }^{\mathrm{V}} \mathrm{CMPC}$ Celulose Riograndense, Guaíba, RS, Brasil. 
species to Brazilian soil and climate conditions and the availability of technologies that facilitate vegetative propagation and rapid growth (LOPES et al., 2004). According to SCHNEIDER et al. (1996), the genus has a wide acceptance among producers, because, in addition to its use as an energy source, the wood is also used in the production of cellulose, particleboard and fiber.

There is growing acceptance of eucalyptus for lumber production due to its increased familiarity, disclosure and availability, as well as pressure to reduce the use of native woods for this purpose (FERREIRA et al., 2004). Bulk materials are needed for the production of logs for sawmills, which implies increased care in its management, including forestry interventions such as pruning and thinning. For this reason, volume is of the most important data needed to ascertain the potential of a stand, given that this feature provides information needed to evaluate the timber stock and the production potential of forests (THOMAS et al., 2006). In equations used to estimate individual growth, the volume is the dependent variable, associated with independent variables easily measured in the forest, such as diameter at breast height and plant height (MACHADO et al., 2002).

In eucalyptus improvement programs, trunk diameter at breast height and height are common measurements, and these traits present great genetic variability. To determine the mean of these traits, without estimation errors, it would be necessary to measure all plants of the forest stand (population). In practice, this would result in intensive labor and the need for more human and financial resources, making it impracticable in most cases. A suitable alternative is to measure a representative part (sample) of the forest stand. The quality of this research depends on the sample size, because if it is insufficient, imprecise mean estimations will be obtained and if it is too big, time and resources will be spent in vain (ZANON et al., $1997)$. The size of this sample is directly proportional to the desired precision and the variability of the data of this trait is inversely proportional to the estimation error allowed a priori by the researcher (BUSSAB \& MORETTIN, 2011). In this context, it is important to determine the number of plants that must be evaluated to enable accurate inferences about these traits.

A number of studies have been carried out in eucalyptus on aspects related to experimental planning, such as experimental alternatives for evaluation of progenies and clones (SOUZA et al., 2003), the ideal size of the experimental plot (ZANON \& STORCK, 1997; SILVA et al., 2003) and determination of sample size (ZANON et al., 1997; SILVA et al., 2007). In general, these studies have shown benefits in terms of improving experimental precision from proper experimental planning. They have also shown that there is variability in the experimental planning among traits and among evaluation ages.

For the assessment of diameter at breast height, total height of the tree and total volume of Eucalyptus saligna Smith plants, the ideal plot size was considered 9 to 25 plants aged five-anda-half-years-old, and four plants in experiments with 15 month-old plants (ZANON \& STORCK, 1997). In eucalyptus clonal tests to assess height, diameter at $1.3 \mathrm{~m}$ and volume, the ideal size of the experimental plot was greater at seven years when compared to three years of age, with five to ten plants providing good experimental precision (SILVA et al., 2003). The ideal sample size for seedlings of Eucalyptus saligna Smith, obtained in a study in a forest nursery, with eight trays of 96 wells, was 26 seedlings per treatment for a minimum of $10 \%$ significant difference, and of nine seedlings per treatment, when the difference was $20 \%$ for the collection diameter. For plant height, the ideal sample size was 23 seedlings, for a difference of $10 \%$, and eight seedlings, for a $20 \%$ difference (ZANON et al., 1997).

It is assumed that sample size differs among traits and eucalyptus hybrids. However, research with this focus is scarce and; therefore, new studies are important to obtain relevant data. Thus, the objective of this study was to determine the sample size (number of plants) needed to estimate average trunk diameter at breast height and plant height of inter-specific eucalyptus hybrids.

\section{MATERIALS AND METHODS}

In this study, it was used the genetic material from a clonal test of inter-specific hybrids of Eucalyptus urophylla S.T. Blake, E. globulus Labill., E. maidenii F. Muell., E. saligna Smith, E. grandis W. Mill ex Maiden, E. pellita F. Muell., E. resinifera Smith in J. White, E. kirtoniana $\mathrm{F}$. Muell. and $\boldsymbol{E}$. dunnii Maiden (Table 1). Inter-specific hybridizations (12 hybrids) were produced, from which 125 clones were selected. The plants 
Table 1 - Number of clones, minimum and maximum number of plants per clone and total number of plants evaluated in 12 inter-specific hybrids of eucalyptus.

\begin{tabular}{|c|c|c|c|c|c|c|}
\hline \multirow{2}{*}{$\mathrm{N}^{\mathrm{o}}$} & \multicolumn{2}{|c|}{---------------------------------Genitors of hybrids-------------------------------- } & \multirow{2}{*}{ Clones } & \multicolumn{2}{|c|}{------Plants per clone-------- } & \multirow{2}{*}{ Total } \\
\hline & Feminine & Masculine & & Minimum & Maximum & \\
\hline 1 & Eucalyptus globulus & Eucalyptus grandis & 1 & 56 & 56 & 56 \\
\hline 2 & Eucalyptus grandis & Eucalyptus dunnii & 3 & 52 & 58 & 168 \\
\hline 3 & Eucalyptus grandis & Eucalyptus maidenii & 1 & 58 & 58 & 58 \\
\hline 4 & Eucalyptus grandis & Eucalyptus urophylla & 7 & 55 & 60 & 403 \\
\hline 5 & Eucalyptus maidenii & Eucalyptus grandis & 1 & 54 & 54 & 54 \\
\hline 6 & Eucalyptus pellita & Eucalyptus globulus & 5 & 43 & 58 & 253 \\
\hline 7 & Eucalyptus resinifera & Eucalyptus globulus & 2 & 26 & 52 & 78 \\
\hline 8 & Eucalyptus saligna & Eucalyptus maidenii & 3 & 32 & 57 & 140 \\
\hline 9 & Eucalyptus urophylla & Eucalyptus globulus & 65 & 19 & 60 & 3,444 \\
\hline 10 & Eucalyptus urophylla & Eucalyptus grandis & 15 & 51 & 60 & 869 \\
\hline 11 & Eucalyptus urophylla & Eucalyptus kirtoniana & 1 & 59 & 59 & 59 \\
\hline 12 & Eucalyptus urophylla & Eucalyptus maidenii & 21 & 34 & 60 & 1,112 \\
\hline Total & & & 125 & 19 & 60 & 6,694 \\
\hline
\end{tabular}

of these 125 clones were propagated by minicutting to obtain 7,332 seedlings. The number of seedlings per clone fluctuated between 36 and 60 . The 7,332 seedlings were planted with a spacing of $3.0 \times 3.0 \mathrm{~m}$ in August 2003, at an experimental area of 7.3 ha belonging to the company, CMPC Celulose Riograndense, located in Tapes County, State of Rio Grande do Sul $\left(30^{\circ} 34^{\prime} 34^{\prime \prime}\right.$, , $51^{\circ} 30^{\prime} 50^{\prime \prime} \mathrm{W}$ and $103 \mathrm{~m}$ of altitude). In 6,694 plants, the following traits were measured: trunk diameters at a breast height at three (DBH3, in $\mathrm{cm}$ ) and seven years of age (DBH7, in $\mathrm{cm})$ and plant height at the age of seven ( $\mathrm{H} 7$, in $\mathrm{m})$. Diameter measurements were made with a tape measure and height measurements were made with a Vertex III (Haglöf, Sweden).

For each trait (DBH3, DBH7 and H7) measured in plants from each of the 12 hybrids, the following statistical measures were calculated: minimum, maximum, mean, variance, standard deviation, standard error, and coefficient of variation, followed by Bartlett's test (STEEL et al., 1997) at 5\% probability of error, to test the hypothesis of homogeneity of variances among the hybrids (12 variances) in each trait ( 3 tests).

The sample size (number of plants) was determined by re sampling with replacement (FERREIRA, 2009). Initially for the re samplings, 599 sample sizes were planned for each trait in each hybrid, with an initial sample size of two plants, and the remaining obtained at increments until reaching
600 plants. Thus, the following sample sizes were planned: $2,3,4, \ldots, 600$ plants.

Then, for each planned sample size, in each trait of each hybrid, 10,000 re samplings with replacement were performed. The mean was estimated for each simulated re sampling. Thus, for each sample size for each trait of each hybrid, 10,000 mean estimations were obtained (FERREIRA, 2009) and the minimum, 2.5 percentile, mean, maximum, and 97.5 percentile were determined. Then, the amplitude of the $95 \%$ confidence interval was calculated by the difference between the 97.5 percentile and the 2.5 percentile. Next, the sample size (number of plants) was determined for estimating the mean of each trait of each hybrid for different precisions. For this determination, an initial size of two plants was used and the sample size was considered to be the number of plants from which the amplitude of the $95 \%$ confidence interval was less than or equal to $10 \%$ (greater precision), $11 \%, 12 \%, 13 \%$, $14 \%, 15 \%, 16 \%, 17 \%, 18 \%, 19 \%$ and $20 \%$ (least precision) of the mean estimation.

The minimum, 2.5 percentile, mean, 97.5 percentile, and maximum values of the sample sizes for trunk diameter at breast height at the age of seven of the inter-specific hybrid $\boldsymbol{E}$. grandis $\times$ E. dunnii were plotted on a graph. The trait of this hybrid was represented graphically, due to the greater sample size required for its mean estimation. A graphical representation with an interval of 10 plants was selected for an ideal visual 
representation. Statistical analyses were performed using the program R (R Development Core Team, 2014) and Microsoft Office Excel.

\section{RESULTS AND DISCUSSION}

Among the 12 inter-specific hybrids of eucalyptus, the mean trunk diameter at breast height at three (DBH3) and seven years of age (DBH7) fluctuated from $10.8 \mathrm{~cm}$ to $14.3 \mathrm{~cm}$ and from $11.7 \mathrm{~cm}$ to $22.6 \mathrm{~cm}$, respectively. Tree height at age seven (H7) ranged between 19.6 and $29.4 \mathrm{~m}$ (Table 2 ). These values were expected for these hybrids and were similar to those reported by KRUSCHEWSKY et al. (2007) who studied the inter-specific hybrid Eucalytus

Table 2 - Minimum, maximum, mean, variance, standard deviation, standard error, and coefficient of variation (CV\%) of trunk diameters at breast height at 3 and 7 years and plant height at 7 years measured in plants of 12 inter-specific hybrids of eucalyptus.

\begin{tabular}{|c|c|c|c|c|c|c|c|c|c|}
\hline \multirow{2}{*}{ № } & \multicolumn{2}{|c|}{----Genitors of hybrids---------- } & \multirow{2}{*}{ Minimum } & \multirow{2}{*}{ Maximum } & \multirow{2}{*}{ Mean } & \multirow{2}{*}{ Variance } & \multirow{2}{*}{ Standard Dev } & \multirow{2}{*}{ Standard Error } & \multirow{2}{*}{$\mathrm{CV}(\%)$} \\
\hline & Feminine & Masculine & & & & & & & \\
\hline & & 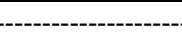 & Trunk diam & er at breast & ight at 3 & $\mathrm{rs}$, in cm-- & 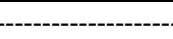 & -------- & -------- \\
\hline 1 & E.globulus & E.grandis & 5.8 & 15.3 & 12.9 & 3.50 & 1.87 & 0.25 & 14.47 \\
\hline 2 & E.grandis & E.dunnii & 5.3 & 16.7 & 12.3 & 5.70 & 2.39 & 0.18 & 19.45 \\
\hline 3 & E.grandis & E.maidenii & 8.3 & 16.6 & 14.3 & 2.71 & 1.65 & 0.22 & 11.54 \\
\hline 4 & E.grandis & E.urophylla & 2.2 & 18.3 & 13.4 & 5.65 & 2.38 & 0.12 & 17.70 \\
\hline 5 & E.maidenii & E.grandis & 10.2 & 15.8 & 13.8 & 1.55 & 1.25 & 0.17 & 9.02 \\
\hline 6 & E.pellita & E.globulus & 7.3 & 17.0 & 11.7 & 2.16 & 1.47 & 0.09 & 12.54 \\
\hline 7 & E.resinifera & E.globulus & 7.5 & 13.4 & 10.8 & 1.81 & 1.34 & 0.15 & 12.42 \\
\hline 8 & E.saligna & E.maidenii & 4.3 & 18.7 & 13.3 & 4.87 & 2.21 & 0.19 & 16.66 \\
\hline 9 & E.urophylla & E.globulus & 3.0 & 19.9 & 13.1 & 4.38 & 2.09 & 0.04 & 15.99 \\
\hline 10 & E.urophylla & E.grandis & 2.1 & 20.9 & 13.5 & 4.97 & 2.23 & 0.08 & 16.52 \\
\hline 11 & E.urophylla & E.kirtoniana & 4.6 & 17.2 & 13.2 & 3.67 & 1.91 & 0.25 & 14.50 \\
\hline 12 & E.urophylla & E.maidenii & 3.9 & 17.5 & 12.0 & 4.82 & 2.20 & 0.07 & 18.26 \\
\hline & & & -Trunk dian & ter at breast & leight at & yrs, in cm-- & & & -------- \\
\hline 1 & E.globulus & E.grandis & 8.1 & 30.8 & 21.7 & 35.20 & 5.93 & 0.79 & 27.28 \\
\hline 2 & E.grandis & E.dunnii & 7.9 & 31.4 & 17.3 & 44.53 & 6.67 & 0.52 & 38.56 \\
\hline 3 & E.grandis & E.maidenii & 9.2 & 27.7 & 22.1 & 11.06 & 3.33 & 0.44 & 15.04 \\
\hline 4 & E.grandis & E.urophylla & 6.3 & 34.1 & 22.6 & 29.35 & 5.42 & 0.27 & 23.94 \\
\hline 5 & E.maidenii & E.grandis & 11.5 & 24.2 & 18.2 & 9.35 & 3.06 & 0.42 & 16.82 \\
\hline 6 & E.pellita & E.globulus & 7.2 & 21.6 & 12.7 & 3.67 & 1.92 & 0.12 & 15.09 \\
\hline 7 & E.resinifera & E.globulus & 7.5 & 17.2 & 11.7 & 3.68 & 1.92 & 0.22 & 16.35 \\
\hline 8 & E.saligna & E.maidenii & 5.6 & 26.1 & 17.3 & 20.54 & 4.53 & 0.38 & 26.20 \\
\hline 9 & E.urophylla & E.globulus & 4.0 & 34.5 & 18.3 & 31.92 & 5.65 & 0.10 & 30.90 \\
\hline 10 & E.urophylla & E.grandis & 5.5 & 35.0 & 19.6 & 30.91 & 5.56 & 0.19 & 28.33 \\
\hline 11 & E.urophylla & E.kirtoniana & 9.9 & 29.2 & 20.2 & 21.20 & 4.60 & 0.60 & 22.82 \\
\hline 12 & E.urophylla & E.maidenii & 4.9 & 29.3 & 16.0 & 21.69 & 4.66 & 0.14 & 29.06 \\
\hline 1 & E.globulus & E.grandis & 9.0 & 34.5 & 27.6 & 25.35 & 5.04 & 0.67 & 18.25 \\
\hline 2 & E.grandis & E.dunnii & 11.4 & 36.6 & 24.0 & 44.75 & 6.69 & 0.52 & 27.92 \\
\hline 3 & E.grandis & E.maidenii & 13.9 & 32.7 & 29.4 & 8.93 & 2.99 & 0.39 & 10.16 \\
\hline 4 & E.grandis & E.urophylla & 8.5 & 35.0 & 28.2 & 27.81 & 5.27 & 0.26 & 18.70 \\
\hline 5 & E.maidenii & E.grandis & 17.7 & 31.8 & 23.7 & 9.52 & 3.09 & 0.42 & 13.02 \\
\hline 6 & E.pellita & E.globulus & 11.7 & 27.8 & 19.6 & 7.80 & 2.79 & 0.18 & 14.27 \\
\hline 7 & E.resinifera & E.globulus & 13.7 & 27.6 & 19.9 & 11.22 & 3.35 & 0.38 & 16.83 \\
\hline 8 & E.saligna & E.maidenii & 8.9 & 33.1 & 24.1 & 24.86 & 4.99 & 0.42 & 20.66 \\
\hline 9 & E.urophylla & E.globulus & 7.2 & 37.5 & 24.8 & 31.72 & 5.63 & 0.10 & 22.75 \\
\hline 10 & E.urophylla & E.grandis & 7.5 & 36.4 & 25.5 & 30.22 & 5.50 & 0.19 & 21.54 \\
\hline 11 & E.urophylla & E.kirtoniana & 13.3 & 33.4 & 26.4 & 21.98 & 4.69 & 0.61 & 17.74 \\
\hline 12 & E.urophylla & E.maidenii & 6.9 & 34.7 & 22.9 & 32.68 & 5.72 & 0.17 & 24.97 \\
\hline
\end{tabular}


camaldulensis $\times$ E. urophylla at three years of age, which presented a diameter at breast height of between $10.46 \mathrm{~cm}$ and $14.19 \mathrm{~cm}$. VILAS BÔAS et al. (2009) also reported $15.6 \mathrm{~cm}$ for diameter at breast height and $23.6 \mathrm{~m}$ plant height in 8 -yr-old E. urophylla.

Based on minimum, maximum, variance, standard deviation, standard error, and coefficient of variation for DBH3, DBH7 and H7 of each hybrid, it can be inferred that there is variability among the traits within each hybrid and among the hybrids within each trait (Table 2). DBH7 presented greater coefficients of variation $(15.04 \% \leq \mathrm{CV} \leq 38.56 \%)$ when compared to $\mathrm{DBH} 3$ $(9.02 \% \leq \mathrm{CV} \leq 19.45 \%)$. This greater variability is probably due to environmental impacts on plants and competition among them. Studying the ideal size of the experimental plot in eucalyptus clonal tests for growth characteristics, such as height, diameter at $1.3 \mathrm{~m}$ height and volume, evaluated at 3, 4, 5, 6 and 7 years of age, SILVA et al. (2003) reported that with increasing age, there was a higher need plants in the plot. The authors believed this occur due to greater competition between plants in the plot for natural resources and increasing interaction between plants and the environment over time, causing greater variability. In the present study, $\mathrm{H} 7$ presented intermediate variation coefficients $(10.16 \% \leq \mathrm{CV} \% \leq 27.92 \%)$. The mean coefficient of variation in the 12 hybrids was $24.20 \%$, $18.90 \%$ and $14.92 \%$, respectively, for $\mathrm{DBH} 7, \mathrm{H} 7$ and DBH3. Therefore, based on these measures of variability, in order obtain a mean estimation with the same precision, a greater sample size can be predicted for the DBH7 measurement, followed by $\mathrm{H} 7$ and $\mathrm{DBH} 3$. Sample size variability among traits was also observed in seedlings of Eucalyptus saligna Smith (ZANON et al., 1997) and of Cabralea canjerana (Vell.) Mart.) (CARGNELUTTI FILHO et al., 2012).

The Bartlett test $\left(\chi_{\text {calc }}^{2}\right)$ employed among the variances of the 12 hybrids gave values of 134, 522 and 265 for the traits DBH3, DBH7 and $\mathrm{H} 7$, respectively. The p-values (minimum level of significance), in the three tests were less than 0.05 . These results demonstrate that the variances of the 12 hybrids, in each trait, were heterogeneous $(\mathrm{P} \leq 0.05)$. Thus, it can be inferred that the sample size for mean estimation of these traits will differ among these inter-specific hybrids of eucalyptus.

The proper growth of eucalyptus plants and the variability existing among the traits within each hybrid and among the hybrids within each trait qualify this database for the proposed study, and revealed the need to determine the sample size for each trait and hybrid. Therefore, the data from this study can aid researchers in sample planning, where the trait and the hybrid under evaluation should be taken into consideration.

The sample sizes for mean estimation of eucalyptus traits, with an amplitude of the $95 \%$ confidence interval equal to $10 \%$ of the mean estimation (greater precision), ranged from 14 (DBH3 of the hybrid $\boldsymbol{E}$. maidenii $\times \boldsymbol{E}$. grandis) and 226 plants (DBH7 of the hybrid $\boldsymbol{E}$. grandis $\times$ E. dunnii) (Table 3 and Figure 1). These results confirmed the above-mentioned inferences about the existence of sample size variability among traits within each hybrid and among hybrids within each trait. At the other extreme, that is, at an amplitude of $95 \%$ confidence interval equal to $20 \%$ of the mean estimation (least precision), sample sizes varied between 4 and 59 plants. At the other precision levels $(11 \%, 12 \%, 13 \%, 14 \%, 15 \%, 16 \%$, $17 \%, 18 \%$ and $19 \%$ ), as expected, the sample sizes were intermediate.

As the variances were heterogeneous among the hybrids within each trait, the sample size of the hybrid with greatest variability guarantees precision equal to or superior to the other hybrids. Thus, based on the hybrid with the greatest variability $(E$. grandis $\times E$. dunnii) for mean estimation of trunk diameter at breast height at three and seven years of age and plant height at seven, with an amplitude of $95 \%$ confidence interval equal to $20 \%$ of the mean estimation, it is sufficient to have a sample size of 16,59 and 31 plants, respectively (Table 3 ).

In practice, measuring 59 plants of eucalyptus (greatest sample size among the traits and hybrids) ensures obtaining means with $20 \%$ precision for the characters DBH3, DBH7 and $\mathrm{H} 7$ of the 12 inter-specific hybrids (Table 3 and Figure 1). The researcher can define the desired error in function of reasonable and acceptable values in their research. Evidently, if greater errors can be tolerated (least precision), smaller sample sizes can be utilized. Therefore, the information provided in this study serves as a reference for the researcher to evaluate, along with constraints of time, human and financial resources and experimental material, which is the most adequate sampling size for each trait and hybrid of eucalyptus. 
Table 3 - Sample size (number of plants) for mean estimation of trunk diameter at breast height at 3 and 7 years and plant height at 7 years, measured in plants of 12 inter-specific hybrids of eucalyptus, for amplitudes of the $95 \%$ confidence interval equal to $10 \%, 11 \%$, $12 \%, \ldots, 20 \%$ of the mean estimation.

\begin{tabular}{|c|c|c|c|c|c|c|c|c|c|c|c|c|c|}
\hline \multirow{2}{*}{$\mathrm{N}^{\mathrm{o}}$} & \multicolumn{2}{|c|}{------Genitors of hybrids-------- } & \multirow{2}{*}{$10 \%$} & \multirow{2}{*}{$11 \%$} & \multirow{2}{*}{$12 \%$} & \multirow{2}{*}{$13 \%$} & \multirow{2}{*}{$14 \%$} & \multirow{2}{*}{$15 \%$} & \multirow{2}{*}{$16 \%$} & \multirow{2}{*}{$17 \%$} & \multirow{2}{*}{$18 \%$} & \multirow{2}{*}{$19 \%$} & \multirow{2}{*}{$20 \%$} \\
\hline & Feminine & Masculine & & & & & & & & & & & \\
\hline & & & $-----\cdot$ & Trunk & ameter & breast & ight at & yrs-----. & - & ------ & ----- & ------- & ------ \\
\hline 1 & E.globulus & E.grandis & 33 & 27 & 23 & 20 & 18 & 16 & 14 & 12 & 11 & 11 & 9 \\
\hline 2 & E.grandis & E.dunnii & 57 & 48 & 42 & 35 & 30 & 28 & 24 & 21 & 19 & 17 & 16 \\
\hline 3 & E.grandis & E.maidenii & 21 & 18 & 16 & 13 & 12 & 10 & 9 & 8 & 8 & 7 & 6 \\
\hline 4 & E.grandis & E.urophylla & 48 & 42 & 35 & 29 & 25 & 22 & 20 & 18 & 16 & 15 & 13 \\
\hline 5 & E.maidenii & E.grandis & 14 & 12 & 10 & 9 & 8 & 7 & 6 & 6 & 5 & 5 & 4 \\
\hline 6 & E.pellita & E.globulus & 26 & 21 & 18 & 16 & 14 & 12 & 11 & 10 & 9 & 8 & 8 \\
\hline 7 & E.resinifera & E.globulus & 25 & 21 & 17 & 15 & 13 & 12 & 11 & 9 & 9 & 8 & 7 \\
\hline 8 & E.saligna & E.maidenii & 42 & 37 & 31 & 27 & 23 & 20 & 18 & 16 & 15 & 13 & 13 \\
\hline 9 & E.urophylla & E.globulus & 41 & 34 & 29 & 26 & 22 & 19 & 18 & 15 & 14 & 13 & 11 \\
\hline 10 & E.urophylla & E.grandis & 44 & 36 & 31 & 26 & 22 & 20 & 18 & 16 & 14 & 13 & 12 \\
\hline 11 & E.urophylla & E.kirtoniana & 33 & 28 & 24 & 20 & 18 & 16 & 15 & 13 & 12 & 11 & 10 \\
\hline 12 & E.urophylla & E.maidenii & 50 & 41 & 36 & 31 & 27 & 24 & 22 & 20 & 18 & 16 & 15 \\
\hline 1 & E.globulus & E.grandis & 111 & $\begin{array}{l}\text { runk d } \\
92\end{array}$ & $\begin{array}{c}\text { meter a } \\
78\end{array}$ & $\begin{array}{l}\text { reast } 1 \\
68\end{array}$ & 60 & 51 & 46 & 41 & 36 & 32 & 31 \\
\hline 2 & E.grandis & E.dunnii & 226 & 186 & 157 & 133 & 116 & 102 & 86 & 79 & 72 & 63 & 59 \\
\hline 3 & E.grandis & E.maidenii & 35 & 30 & 26 & 22 & 20 & 17 & 15 & 13 & 12 & 11 & 10 \\
\hline 4 & E.grandis & E.urophylla & 91 & 72 & 63 & 54 & 47 & 40 & 35 & 32 & 29 & 26 & 24 \\
\hline 5 & E.maidenii & E.grandis & 44 & 38 & 31 & 26 & 23 & 20 & 19 & 16 & 14 & 13 & 13 \\
\hline 6 & E.pellita & E.globulus & 35 & 31 & 27 & 22 & 20 & 18 & 16 & 14 & 12 & 11 & 10 \\
\hline 7 & E.resinifera & E.globulus & 42 & 35 & 29 & 26 & 22 & 19 & 17 & 16 & 14 & 13 & 12 \\
\hline 8 & E.saligna & E.maidenii & 103 & 87 & 74 & 63 & 53 & 48 & 43 & 37 & 34 & 31 & 28 \\
\hline 9 & E.urophylla & E.globulus & 148 & 122 & 101 & 87 & 77 & 64 & 59 & 52 & 47 & 41 & 38 \\
\hline 10 & E.urophylla & E.grandis & 125 & 100 & 88 & 74 & 63 & 56 & 48 & 44 & 40 & 34 & 32 \\
\hline 11 & E.urophylla & E.kirtoniana & 81 & 65 & 55 & 48 & 42 & 35 & 31 & 28 & 26 & 23 & 21 \\
\hline 12 & E.urophylla & E.maidenii & 130 & 106 & 92 & 79 & 66 & 59 & 52 & 45 & 42 & 37 & 34 \\
\hline 1 & E.globulus & E.grandis & 52 & 42 & 37 & 31 & 27 & 25 & 21 & 18 & 17 & 16 & 14 \\
\hline 2 & E.grandis & E.dunnii & 121 & 97 & 86 & 69 & 61 & 54 & 46 & 42 & 38 & 35 & 31 \\
\hline 3 & E.grandis & E.maidenii & 17 & 14 & 13 & 11 & 10 & 8 & 8 & 7 & 7 & 6 & 6 \\
\hline 4 & E.grandis & E.urophylla & 53 & 45 & 38 & 33 & 29 & 25 & 22 & 20 & 18 & 16 & 15 \\
\hline 5 & E.maidenii & E.grandis & 26 & 22 & 20 & 17 & 15 & 13 & 11 & 10 & 9 & 8 & 8 \\
\hline 6 & E.pellita & E.globulus & 33 & 27 & 23 & 20 & 17 & 15 & 14 & 12 & 11 & 10 & 9 \\
\hline 7 & E.resinifera & E.globulus & 44 & 38 & 31 & 27 & 23 & 20 & 18 & 17 & 15 & 13 & 12 \\
\hline 8 & E.saligna & E.maidenii & 65 & 56 & 47 & 40 & 35 & 31 & 27 & 24 & 21 & 19 & 18 \\
\hline 9 & E.urophylla & E.globulus & 82 & 67 & 57 & 49 & 42 & 37 & 33 & 29 & 26 & 24 & 20 \\
\hline 10 & E.urophylla & E.grandis & 72 & 60 & 51 & 45 & 37 & 33 & 27 & 26 & 23 & 21 & 19 \\
\hline 11 & E.urophylla & E.kirtoniana & 47 & 41 & 34 & 30 & 26 & 22 & 20 & 18 & 16 & 15 & 13 \\
\hline 12 & E.urophylla & E.maidenii & 96 & 79 & 71 & 56 & 50 & 44 & 40 & 34 & 31 & 28 & 26 \\
\hline
\end{tabular}

\section{CONCLUSION}

There is an increase in the sample size (number of plants) for mean estimation of trunk diameter at breast height at three years, plant height at seven years and of trunk diameter at breast height at seven years of age, in that order.
For a mean estimation of trunk diameter at breast height at three and seven years and plant height at seven years in the inter-specific hybrids of eucalyptus studied, with amplitude of 95\% confidence interval equal to $20 \%$ of the mean estimation, a sufficient sample size is 16,59 and 31 plants, respectively. 


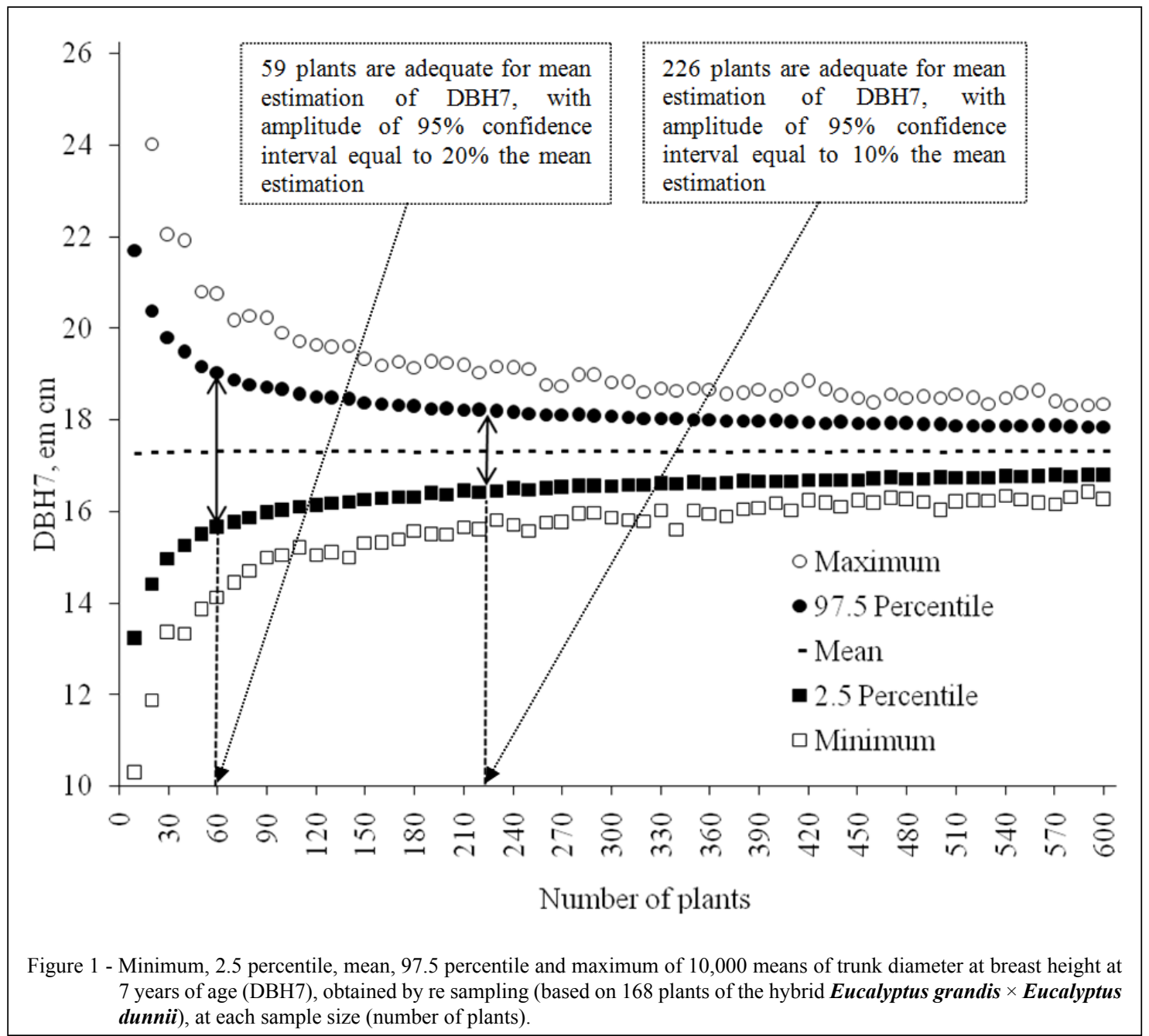

\section{ACKNOWLEDGEMENTS}

To the Conselho Nacional de Desenvolvimento Científico e Tecnológico $(\mathrm{CNPq})$ for granting scholarships to the authors. To the company CMPC Celulose Riograndense for support and technical assistance to carry out the work.

\section{REFERENCES}

BUSSAB, W.O.; MORETTIN, P.A. Estatística básica. 7.ed. São Paulo: Saraiva, 2011. 540p.

CARGNELUTTI FILHO, A. et al. Sample size for evaluating the height and diameter of seedlings Cabralea canjerana. Ciência Rural, v.42, p.1204-1211, 2012. Available from: <http://www. scielo.br/pdf/cr/v42n7/a19912cr5829.pdf $>$. Accessed: Nov. 21, 2015. doi: 10.1590/S0103-84782012000700011.

FERREIRA, D.F. Estatística básica. 2.ed. Lavras: UFLA, 2009.664p.

FERREIRA, S. et al. Influence of tangential break down methods on the yield and on the quality of Eucalyptus spp. sawn timber.
Cerne, v.10, p.10-21, 2004. Available from: <http://www.redalyc. org/pdf/744/74410102.pdf>. Accessed: Nov. 21, 2015.

KRUSCHEWSKY, G.C. et al. Structural arrangement and growth dynamics of Eucalyptus spp., in an agrosilvipastoral system on the Cerrado-MG. Cerne, v.13, p.360-367, 2007. Available from: $<$ http://www.redalyc.org/articulo.oa?id=74413403>. Accessed: Nov. 21, 2015.

LOPES; M.C. et al. Grouping of Eucalyptus grandis selected trees in function of the dendrometric variables and the technological characteristics of wood. Ciência Florestal, v.14, p.133-144, 2004. Available from: $<$ http://cascavel.ufsm.br/revistas/ojs-2.2.2/index.php/ cienciaflorestal/article/view/1813/1077>. Accessed: Nov. 21, 2015.

MACHADO, S.A. et al. Modelagem do volume individual para diferentes idades e regimes de desbaste em plantações de Pinus oocarpa. Revista Ciências Exatas e Naturais, v.4, p.185-196, 2002. Available from: <http://revistas.unicentro.br/index.php/ RECEN/article/view/462/617>. Accessed: Nov. 21, 2015.

R DEVELOPMENT CORE TEAM. R: a language and environment for statistical computing. Vienna: R Foundation for Statistical

Ciência Rural, v.46, n.7, jul, 2016. 
Computing, 2014. Available from: <http://www.R-project.org>. Accessed: Nov. 21, 2015

SCHNEIDER, P.R. et al. Taper and assortment of wood for Eucalyptus grandis maiden to the State of Rio Grande do Sul. Ciência Florestal, v.6, p.79-88, 1996. Available from: <http:// coral.ufsm.br/cienciaflorestal/artigos/v6n1/art8v6n1.pdf>. Accessed: Nov. 21, 2015

SILVA, G.F. et al. Evaluation of the influence of varying sample sizes and composition on the precision of a hypsometric relation for Eucalyptus grandis. Revista Árvore, v.31, p.685694, 2007. Available from: <http://www.scielo.br/pdf/rarv/ v31n4/13.pdf $>$. Accessed: Nov. 21, 2015. doi: 10.1590/S010067622007000400013

SILVA, R.L. et al. Determination of the experimental optimun plot size by maximum modified curvation, interclass correlation coefficient and visual analysis methods in eucalypt clonal test. Revista Árvore, v.27, p.669-676, 2003. Available from: <http:// www.scielo.br/pdf/rarv/v27n5/a09v27n5.pdf>. Accessed: Nov. 21, 2015. doi: 10.1590/S0100-67622003000500009.

SOUZA, E.A. et al. Experimental alternatives for evaluation of progenies and clones in eucalyptus breeding programs. Revista
Árvore, v.27, p.427-434, 2003. Available from: <http://www. scielo.br/pdf/rarv/v27n4/a02v27n4.pdf>. Accessed: Nov. 21, 2015. doi: 10.1590/S0100-67622003000400002.

THOMAS, C. et al. Comparative volume equations adjusted with data of stem measurements and stem analysis. Ciência Florestal, v.16, p.319-327, 2006. Available from: $<$ http://cascavel. ufsm.br/revistas/ojs-2.2.2/index.php/cienciaflorestal/article/ view/1911/1155>. Accessed: Nov. 21, 2015.

VILAS BÔAS, O. et al. Crescimento comparativo de espécies de Eucalyptus e Corymbia no município de Marília, SP. Revista do Instituto Florestal, v.21, p.63-72, 2009. Available from: <http:// www.iflorestal.sp.gov.br/RIF/RevistaIF/RIF21-1/RIF21-1_63-72. pdf $>$. Accessed: Nov. 21, 2015.

ZANON, M.L.B. et al. Sample size for experiments of Eucalyptus saligna Smith in the tree nursery. Ciência Florestal, v.7, p.133138, 1997. Available from: <http://coral.ufsm.br/cienciaflorestal/ artigos/v7n1/art11v7n1.pdf>. Accessed: Nov. 21, 2015.

ZANON, M.L.B.; STORCK, L. Experimental plot size for Eucalyptus saligna Smith. Ciência Rural, v.27, p.589-593, 1997. Available from: <http://www.scielo.br/pdf/cr/v27n4/a11v27n4. pdf $>$. Accessed: Nov. 21, 2015. 